\title{
Luxury and sustainability: a common future? The match depends on how consumers define luxury
}

\author{
Jean-Noël Kapferer* \\ INSEEC Group, \\ 14 Rue de Prony, \\ 75017 Paris, France \\ Email: jnkapferer@inseec.com \\ *Corresponding author
}

\author{
Anne Michaut \\ HEC Paris, \\ 1 rue de la Libération, \\ 78351 Jouy-en-Josas, France \\ Email: michaut@hec.fr
}

\begin{abstract}
Sustainability issues have become a challenge for the luxury sector whose continuous success and growth - despite recessions, economic crises and increasing social inequality - appear as a paradox or even a provocation for some critics. Based on a program of multiple surveys involving actual luxury customers, we explain why customers are not concerned about sustainability considerations when they purchase a luxury product. But this apparent uninvolvement hides a more complex reality with high latent expectations towards luxury brands. Fundamentally, the perceived contradiction between luxury and sustainability depends on how luxury is defined by consumers: it is lower for consumers defining luxury in terms of exceptional quality. This is crucial for the defence of the legitimacy of the luxury sector as a whole, and of its most iconic brands for the future.
\end{abstract}

Keywords: sustainability; luxury; corporate social responsibility; CSR; ethics; fashion.

Reference to this paper should be made as follows: Kapferer, J-N. and Michaut, A. (2015) 'Luxury and sustainability: a common future? The match depends on how consumers define luxury', Luxury Research J., Vol. 1, No. 1, pp.3-17.

Biographical notes: Jean-Noël Kapferer is a world academic authority on luxury. An HEC Paris graduate, PhD Kellogg (USA), he analyses the evolving business models of luxury brands. He is the co-author of The Luxury Strategy and author of Kapferer on Luxury. He teaches at HEC Paris, Tsinghua University Beijing, Luxury Business Institute Seoul and is Advisor to the President of INSEEC.

Anne Michaut is an Affiliate Professor at HEC Paris. Her research focuses on new product adoption processes, and also on luxury, sustainable development and entrepreneurship. At HEC Paris, she teaches in the Grande Ecole, MBA, executive MBA, and executive education programs. 


\section{Introduction}

Luxury represents a relatively small sector of the economy compared to the automobile or food industry for instance. Nevertheless, luxury brands attract increased attention and have become highly visible: from large billboards on the streets to business pages of authoritative economic newspapers (International Herald Tribune, Financial Times ...). Today luxury brands are ubiquitous in all capital cities of the world, all airports. It is striking to observe that despite the long-lasting economic turmoil, the luxury sector is doing well with a growth rate beyond 10\% per year since 2009 (Bain \& Co., 2014). Not surprisingly, numerous articles analyse and are seeking to explain this success. In addition, the world of luxury brands attracts attention as they are the highest symbols of the consumption society which now dominates the world.

The downside of this visibility and success is a simultaneous higher exposure to criticism. In the current context, sustainable development has become a key issue for all businesses: it now also includes luxury not so much because of its size - small indeed but because luxury symbolises the growth of a consumption based on other motives than functionality. This has been called the positional economy (Mason, 2000) or the appearance business. As a result, those luxury brands which have a high iconic status are more in the viewfinder of activists such as Greenpeace and other NGO's looking for symbolic trophies of their fight for a better world. During the European controversy regarding the presence of allergens in $90 \%$ of perfumes, No. 5 - the iconic product of Chanel, one of world's most prestigious luxury brands - appeared to be the first one mentioned by rumours, and this all the way to China, thus creating a negative buzz in the Chinese social networks about this expensive brand, depicted by the false rumour as faulty.

These examples clearly show that the reputational risk has become very high for luxury brands. This risk is all the more intense that a criticism emanating from a single consumer can quickly take on gigantic proportions because of social networks. In addition, consumers indicate a growing need for transparency: in France, $80 \%$ believe that companies do not provide enough information about the conditions of manufacture of their products (Rapport Annuel Ethicity, 2013). As early as 2007, luxury brands were criticised for their lack of transparency in Deeper Luxury report (Bendell and Kleanthous, 2007), and still today the lack of transparency is reported by Greenpeace for brands such as Hermès, Chanel Dior and Vuitton (http://www.thefashionduel.com).

Sustainable development has become a pervasive problem for luxury brands (Gardetti and Torres, 2014). More than any other, the luxury sector is highly aware of the risks to brand reputation, so crucial for their pricing power and monetary value (Kapferer and Bastien, 2012; Fombrun and Shanley, 1990). Besides, there is an increasing tendency to support the idea that sustainability can create value. François-Henri Pinault, CEO of Kering, world $\mathrm{N}^{\circ} 2$ luxury group, recently reaffirmed his conviction that an approach based on sustainability would generate new revenue and long-term competitive advantage for the group. Even if - as we shall see below consumer response is still weak, luxury corporations must lead the way. As pointed out by Wheeler et al. (2003), companies can create value through a responsible approach. Also, a high quality that pollutes is no quality at all today.

In this paper, we argue that, because of their high visibility and their commitment to quality, luxury brands are particularly affected by sustainability issues. First, this paper shows that customers' focus on sustainability remains weak or poorly expressed in the 
case of luxury purchases, even less than for fast fashion (C\&A, H\&M,...) for instance not to talk of mass brands (Nike, Gap,...). Yet, deeper analyses uncover a more complex reality in which luxury customers have very high latent expectations about the commitment of luxury brands in sustainability. More strategically, we show that the level of perceived contradiction between luxury and sustainable development differs according to the client's age but also his/her definition of luxury. This is important since younger generations are the future of the luxury sector. Also this sector must carefully manage its image as a whole to prevent public attacks on its legitimacy: it has to choose the definition of luxury (its positioning) which will best protect if not promote its legitimacy. Finally, we suggest that sustainability is now just part of the expected redefinition of what the notion of highest quality should mean today, and propose a number of potential improvements for luxury brands.

\section{Luxury and sustainability: conceptual framework}

Our conceptual framework is based firstly on the classical definition of sustainable development by the World Commission on Environment and Development [Brundtland Commission, (1987), p.47]: "Sustainable development is development that meets the needs of the present without compromising the ability of future generations to meet their own needs". Since then, many research papers have gone beyond this definition, in particular by developing the many facets of sustainable development. Gladwin et al. (1995) identified characteristics such inclusiveness, prudence, connectivity, security and equity as essential components of sustainable development based on a content analysis of various definitions. These components provide us with an important framework for analysing the possible adequacy between luxury and sustainability.

Just as sustainability appears multi-faceted, luxury has multiple facets as well. Many definitions of luxury have been proposed by academics and practitioners. This large number results from the fact that they often reflect individual conceptions of luxury rather than try to define the concept. Instead of adding another definition, their own, in a literature review and re-analysis of three well known scales measuring luxury, De Barnier et al. (2012) have identified the seven common elements characterising luxury, as they emerge from the three main scales adopted to date: these factors are exceptional quality, hedonism (beauty and pleasure), price (expensive), rarity (which is not scarcity), selective distribution and associated personalised services, exclusive character (prestige, privilege), and creativity (art and avant-garde). This paper builds on this working definition of the concept. The seven criteria are all needed to differentiate luxury goods from other types of goods such as premium or fashion goods (Kapferer and Bastien, 2012).

By comparing the components of sustainable development with those of luxury, it becomes possible to identify potential elements of contradiction. For example, all elements related to ostentation will oppose the fairness or social harmony facets of sustainable development. Similarly pleasure, superficiality are opposed to altruism, moderation, ethics. However, unlike fast fashion - also called waste couture (Claudio, 2007) or fast moving consumer goods, the word luxury is also associated with high quality, know-how, slow time, the preservation of hand made traditions, transmission from generation to generation of timeless products: these associations will be in agreement with sustainability. One of the fundamental principles of a true luxury strategy 
(Kapferer and Bastien, 2012) is to produce locally by talented artisans, and respect the sources of raw materials (Kapferer, 2010). Unfortunately, the rapid growth of the luxury sector has attracted new brands, looking for volume and margins: they are mass-tige brands (with an image of luxury but mass-produced) and derogate from the strict luxury rules to increase their margins. The problem is that their names can be associated to the luxury sector, and as such impact the luxury industry image. The desire of always more consumers to have access to the most prestigious brands (Silverstein and Fiske, 2003) has also led luxury brands to offer more affordable products or services, through second or third lines, also through accessories. Luxury has indeed switched to an 'abundant scarcity' model (Kapferer, 2012b), moving away from its fundamental principles. Some so-called luxury brands offer expensive products but do not always follow the founding rules of luxury: they produce in low-wage countries with little control on raw materials and sub-contractants or licensees. Such behaviours - now disclosed by the economic press and the social media - may lead the public to have a negative view of the brands that do not respect the essence of the luxury strategy (Thomas, 2007) in order to meet always increasing profit and volume targets.

In a second step, to avoid taking desires for realities, one needs to question the importance of sustainability criteria in a luxury purchase. It is a fact: sustainability is only rarely mentioned in the selection criteria of luxury brands (Kapferer and Michaut, 2014a, 2014b). As such, luxury is not different from all other sectors. Indeed research keeps on pointing at the inconsistency between attitudes and behaviours when talking about ethical criteria in decision making. People do support corporate social responsibility (CSR) and ethical concerns but are not ready to pay more for them (Bhattacharya and Sen, 2004). A recent research (Leary et al., 2014) has showed that ethical concerns transform into behaviours only if consumers felt their simple action could have a snowball effect and market influence. Ehrich and Irwin (2005) unveiled a troubling fact: consumers tend to purposefully ignore sustainability issues when they purchase, even though they say they are concerned. This willful ignorance has a goal: to protect consumers from negative emotions. This is why luxury purchases are indeed still less impacted by sustainable or ethical criteria: nothing should hurt the dream.

There are very few empirical studies focusing on luxury and sustainable development per se. Achabou and Dekhili (2013) demonstrated that luxury buyers did not value positively the idea of buying a Hermès product made of recycled cotton. Actually the more one is a regular luxury buyer the more one is against purchasing recycled cotton in a luxury product. Recycling means it is no more rare, it loses its prestige. We would add that the cotton becomes impure, drawn from suspect uncontrolled sources. There is no problem however to use recycled material for the packagings themselves (which will be destroyed and wasted). Janssen et al. (2014) have showed that indeed luxury was perceived as compatible with CSR, but only for rare and nonephemeral products (such as jewels). When rarity is applied to ephemeral products (clothing) there was no perception of compatibility. Unfortunately these authors are making a classical conceptual confusion. By definition fashion is ephemeral, but luxury clothes aim at lasting: luxury sells style not fashion. Kapferer and Bastien (2012) have showed how much the luxury business model was different from the fashion business model. Davies et al. (2012) demonstrated that consumers were less likely to take into account ethical criteria when they bought luxury goods than when they bought FMCG goods. In addition they propose a number of explanatory factors: 
a luxury purchases are rare: consumers do not perceive their impact on the environment, unlike mass-produced products such as cotton $\mathrm{T}$ shirts which are devastating the water resources of the planet

b each luxury purchase is a blessed moment, a parenthesis for dreaming: why trouble it with negative ideas about the many dramas on earth?

c people would expect that luxury brands more than any other would take all into account, considering their high price and the fact that they have to obey their already existing national laws about the protection of nature.

Most of these researches have focused on one side of what is called sustainable development: the ecological one. But there are two other pillars: slow growth and social harmony.

Kapferer and Michaut (2014a) found indeed that luxury was felt to be the most contradictory with sustainable development when consumers perceived luxury as 'superficial' and 'creating social unrest'. In this study, although luxury buyers declared they did not care about sustainable development when buying a luxury product, they were also very prompt to react negatively when learning some dissonant news about the luxury brands: those negative news most likely to induce boycott were first engaging cheap workforce to produce luxury goods, then killing animals for their furs, killing three crocodiles to make one single luxury bag, destroying unsold products instead of selling them at a discount web-store, etc.... As soon as questionnaire talk about vivid facts, and abandon abstract yes-saying inducing ethical concepts, consumers get involved. In another study, Kapferer and Michaut (2014b) analysed the determinants of the above identified consumer capacity to mobilise themselves against luxury brands, to boycott them if misbehaviours were discovered concerning sustainable development. The first reason emerging from the regression analysis is "Today the real class is to buy luxury products respectful of the planet", the second being "Considering their price, it is the least one can expect from luxury brands". Surprisingly the motivations of never taking SD into consideration when buying a luxury product are not the same two as above, negatively. In fact ability to boycott is not the contrary of absence of concern: the latter means absence of involvement, the former means positive involvement. Thus what makes people not care about SD when buying: first "I think of my own pleasure at that moment", then "I am unable to tell what brands are doing a lot in terms of SD", thirdly "luxury purchases are too rare to have an impact".

Based on the characteristics of luxury and sustainability mentioned above, one may argue that customers are potentially aware of the likely contradictions between luxury and sustainability. However, sustainability still is a vague concept to many consumers. Bernard Arnault, CEO of LVMH, world $\mathrm{N}^{\circ} 1$ luxury group, summarises the modern luxuries such as: "The ordinary of the extraordinary people and the extraordinary of ordinary people". This sentence seems at the heart of the question of luxury and sustainability. Indeed, consumers are particularly interested in sustainability when they perceive that their choice has an immediate impact (Jones, 1991; Leary et al., 2014). This is the case for consumer products, characterised by highly repeated purchases, but not for the very few purchases of extraordinary luxury goods (Davies et al., 2012). Thus, consumers will perceive more clearly the impact of the 'conscious' collection by H\&M a mass fashion retailer accessible to all - than the one of the Rainforest Alliance certified collection by Gucci. Moreover, in luxury, everything is done for the client to feel unique 
and special: this tends to maximise the feeling of privilege and rarity, minimise the feeling of volume, therefore, of the potential impact of this rare purchase on sustainable development.

In addition, the vast majority of luxury brands have so far remained relatively discreet on the sustainability issue. This silence is not odd in the strategy of luxury brands. Luxury is about making things non-comparable: this is why brands seldom speak about products' characteristics (except quality) or operations (e.g. supply chain) but rather organise events to share their universe, tell stories and legends about their history and their clients. Luxury brands deliver a dream, they do not want to contaminate with information that could harm it, for example by returning to daily or mundane concerns or mundane. When consumers buy a luxury good do they want to learn about sad things concerning the misbehaviour of some actors of the luxury sector? As a result, this discreet attitude clearly does not increase the prominence of sustainability in the choice of customers when they enter a luxury store. However, if sustainability is at times perceived as austere and little in line with the desirability of luxury, new brands have managed to break this rule and bring sustainability at the very heart of their own dream. This is the case for brands like Tesla (electric luxury vehicles designing the dream of a better future) or the Stella McCartney fashion brand, refusing to use real leather since this designer is a vegetalian fan. These examples thus show that sustainability can become in itself an element of desirability and prestige, and therefore be at the heart of the communication of a luxury brand. They also demonstrate that to succeed sustainable brands must follow a luxury strategy: Tesla cars are designed, priced and marketed exactly like dream cars. Would one talk about Stella McCartney if she was not by birth a celebrity, as the daughter of a Beatle?

However, although luxury consumers do not appear to be explicitly interested in the sustainability criterion to purchase luxury brands (Gardetti and Torres, 2014), they nevertheless do have strong expectations. Luxury consumers implicitly hold the belief that luxury brands have the duty of being sustainable, a mission of exemplarity based on their price and promised exceptional quality. There are already many links between the concepts of high rare product quality and sustainability of rare resources. For instance, the international ISO 26000 standard encourages companies to voluntarily commit to sustainability, taken in all its facets. This quality standard includes sustainability in the definition of quality. And this is not the only sign, McAdam and Leonard (2003) particularly studied how quality management can become an example and a catalyst for sustainability management.

\section{Research and hypotheses}

As mentioned earlier in this paper, because of its exceptional nature, luxury is or should be apart from the daily concerns of consumers. Thus, we hypothesise that by entering into a luxury store, the client purposefully ignores issues related to sustainability. This is a form of selective avoidance. However, this does not mean that the luxury client is not sensitive to the issue. In fact, as Davies et al. (2012), we also hypothesise that luxury customers have very high expectations. Everything happens as if the customers do not care about sustainability because they believe that it is the role of brands to be exemplary on this aspect also. 
H1 Luxury customers are likely to ignore sustainability issues in their luxury purchases.

H2 Luxury customers are likely to have high expectations regarding the compliance of luxury brands with sustainability.

Luxury is both a concept and a very prosperous industry. In order to pursue its growth, this industry made of companies, brands, and groups (LVMH, Kering etc...) will need to reinforce its legitimacy (Kapferer, 2015). What facet of luxury is most likely to legitimate this industry? Luxury is plural and each individual potentially has its own definition of the concept of luxury. For this reason, it seems important to study the issue of sustainability in relation with the definition of luxury held by each given customer, not the academic one we selected at the outset of this paper. Indeed, some aspects of luxury show a priori some coherence with sustainability while others seem in opposition. Gladwin et al. (1995) identified five components of sustainability found in many definitions: inclusiveness, prudence, connectivity, security and fairness. There is luxury meanwhile because not everybody can get to it: luxury is discriminatory and its objective in democratic open societies is to create social stratification (Kapferer and Bastien, 2012), which appears at odds with the notion of social equity and harmony. Thus, we assume that customers who define luxury primarily as being exclusive, rare or expensive, perceive a high contradiction between luxury and sustainability. In contrast, clients for whom luxury is all about respect for rare materials and craftsmen (exceptional quality) will instead perceive a low conflict with sustainability. We make no assumption about the hedonic nature of luxury that can be understood in agreement or in conflict with sustainability. This leads to the following hypotheses:

H3 Customers defining luxury based on (a) high price, (b) rarity, (c) exclusivity, perceive a high contradiction between luxury and sustainability while customers defining luxury based on (d) exceptional quality perceive a low contradiction.

Finally, we also assume an effect of age in the perceived contradiction between luxury and sustainability. Several studies have examined the socio-demographic characteristics of responsible consumers. Dickson (2001), as well as a literature review by Roberts in 1995, concluded that the demographics (age, education, income) were not discriminatory for the identification of responsible consumer. Other studies have shown the influence of income, education and social status (Carrigan and Attalla, 2001; Maignan and Ferrell, 2001).

The process of massification of luxury, moving away from the ideal fundamentals of the luxury strategy (exceptional quality, handmade in workshops, small volumes, limited size of clientele) increased in the 1990s when luxury companies have attracted financial groups and Wall Street investors. Looking for endless growth, these groups have applied to luxury the rules of frenzied marketing, creating an ambiguity in the definition of luxury, in contradiction with the principles of sustainability based on some form of rarity. As a result, younger customers are 'born' with a more ambiguous representation of luxury. Indeed, Achabou and Dekhili (2013) found that younger clients were more concerned with sustainable development issues. As a consequence we hypothesise that luxury is perceived as farthest from the sustainability ideals for younger consumers, the new generations.

H4 Perceived contradiction between luxury and sustainability diminishes as customers' age increases. 


\section{Methodology}

The results presented below are derived from a survey conducted in France in 2012 through internet with 966 self-declared luxury customers. It allowed us to test our hypotheses quantitatively.

\subsection{Measures and data collection}

We wanted to include in our sample only luxury customers to conduct this study on the compatibility between luxury and sustainability. What does this core target think, believe? Too often research on luxury includes either convenience samples (students, mostly non-buyers of luxury, hence non-representative of the existing target of luxury brands). In this perspective, we worked with BVA, a market research company, to recruit 1000 actual luxury buyers from their internet national panel. Filtering was carried out by BVA on the basis of the reported purchase in the last 12 months of at least one among five products - presented on a list - beyond a certain price (e.g. champagne above 45 Euros, shoes above 250 Euros, sunglasses above 250 Euros, etc...). Socio-demographic characteristics were known, because they belong to BVA national panel.

Their perception of luxury was operationalised based on the seven criteria defining a 'luxury item' (De Barnier et al., 2012): outstanding quality, hedonism (beauty and pleasure), price (very expensive), rarity, selective distribution and associated services, exclusivity (prestige, privilege, inaccessible), creativity (art and avant-garde). We asked respondents which of these seven attributes defined luxury, in descending order of importance. These respondents were later segmented according to the attribute they designated first, the prototypical trait of luxury for them. For measuring the perceived contradiction between luxury and sustainability, we used two items (Likert scales to 5 points 'strongly agree' to 'strongly disagree') (see these items in Table 3).

\subsection{Sample description}

Among the 1,000 respondents, 966 completed the questionnaire successfully and were included in this study. Respondents include men and women $(54 \%$ and $46 \%$ of the sample respectively). The most represented age ranges are the groups $25-34$ and $35-44$ with just over 20\% each; 18-24 years, 45-54 years and 55-64 years accounted for 15\% each, while the least represented group is constituted by $64-75$ years $(8 \%)$. Finally, the household monthly income is less than $€ 5,000$ for $44 \%$ of respondents, between $€ 5,000$ and $€ 10,000$ for $22 \%$ of respondents and above $€ 10,000$ for $22 \%$. Besides, $12 \%$ of respondents chose not to answer this question. This distribution is consistent with the Market data showing that luxury consumers do not need to be rich to buy luxury personal luxury products but highly desiring them. 
Table 1 Descriptive statistics about the sample

\begin{tabular}{llccc}
\hline \multicolumn{1}{l}{ Frequencies } & $N$ & $\%$ & Valid \% \\
\hline Age $\left(^{*}\right)$ & $18-24$ & 154 & 15.9 & 15.9 \\
& $25-34$ & 334 & 23.2 & 23.2 \\
& $35-44$ & 217 & 22.5 & 22.5 \\
& $45-54$ & 146 & 15.1 & 15.1 \\
& $55-64$ & 153 & 15.8 & 15.8 \\
& $65-75$ & 72 & 7.5 & 7.5 \\
& Total & 966 & 100.0 & 100.0 \\
Gender & Men & 520 & 53.8 & 53.8 \\
& Women & 446 & 46.2 & 46.2 \\
& Total & 966 & 100.0 & \\
& Less than 5,000€ & 427 & 44.2 & 50.0 \\
& Between 5,000 and 10,000€ & 214 & 22.2 & 25.1 \\
& 10,000 and above & 213 & 22.1 & 25.0 \\
& Missing & 112 & 11.6 & \\
& Total & 966 & 100.0 & \\
\hline
\end{tabular}

Notes: $(*)$ age was measured as a continuous variable: $\min =18, \max =75$, mean $=41.04$, std. $\operatorname{dev}=14.76$.

In Table 2, we present respondents' luxury perception. We chose to base ourselves on the first feature mentioned as defining luxury rather than on an analysis of clusters of attributes. Certainly luxury is a complex social object which cannot be defined by a single trait, but according to the semantic theory of prototypes (Kleiber, 1999) the first salient attribute of perception is the most significant too. A majority of our sample defines luxury by its exceptional quality $(33 \%)$, followed by its rarity $(17 \%)$ followed by its exclusivity $(13.2 \%)$, and finally by price $(13 \%)$ or its hedonic nature $(13 \%)$. It resulted in a breakdown of respondents in five representative groups. The most marginal respondents in their definition of luxury (the remaining $10 \%$ distributed on the criteria limited distribution, creativity) were not included in the analyses.

Table 2 Most salient luxury attribute mentioned by respondents

\begin{tabular}{lccc}
\hline First attribute: & $N$ & $\%$ & $\%$ valid \\
\hline Exceptional quality & 319 & 33.0 & 33.5 \\
Rarity & 163 & 16.9 & 17.1 \\
Hedonism (beauty) & 124 & 12.8 & 13.0 \\
Price (very expensive) & 124 & 12.8 & 13.0 \\
Exclusive and excluding & 251 & 13.1 & 13.3 \\
Other* & 96 & 9.9 & 10.1 \\
\hline
\end{tabular}

Note: *Limited distribution, creativity, ... 


\subsection{Analyses}

In preliminary analyses, we analysed respondents' sensitivity to sustainability in relation to their consumption of luxury goods. All items are measured on Likert-type scales (5 points). We split respondents into three groups: those who agreed with the statements (grouping 'strongly agree' and 'agree'), those who 'neither agree nor disagree' and those who do not agree (grouping 'strongly disagree' and 'disagree').

In the next step, we first used a factor analysis for the dependent variable: the perceived contradiction between luxury and sustainability. This variable is measured by two items ("luxury and sustainability are contradictory" and "luxury has little future in our world moving towards sustainability”) (Cronbach's alpha $=.75$, var. explained $=.80$ ). We then established a binary variable based on this factor. Subsequent analyses consisted in comparing the perception of how much sustainable development and luxury were contradictory on the basis of respondents' age and of their own definition of luxury (first salient characteristic quoted).

\section{Results}

Let us start with descriptive statistics: is sustainability a concern for consumers when purchasing luxury items? Table 3 exhibits descriptive statistics of our sample regarding their attitude towards luxury and sustainability.

Table 3 Attitudes about luxury and sustainability ( $\mathrm{n}=966$ luxury customers)

\begin{tabular}{lccc}
\hline & Agree & Neither nor & Disagree \\
\hline When I buy luxury products, I don't care about sustainability & $31.9 \%$ & $30.3 \%$ & $34.9 \%$ \\
$\begin{array}{l}\text { Luxury should be exemplary in terms of sustainability } \\
\text { Given their price, it would be shocking to }\end{array}$ & $71.4 \%$ & $20.6 \%$ & $8.0 \%$ \\
$\begin{array}{l}\text { hear that luxury brands are not compliant } \\
\text { Luxury products are renowned for their }\end{array}$ & $69.0 \%$ & $20.0 \%$ & $11.0 \%$ \\
high quality and longevity & $45.4 \%$ & $35.6 \%$ & $19.0 \%$ \\
$\begin{array}{l}\text { Luxury is a symbol of human inequalities and richness } \\
\text { Luxury makes people buy products far too }\end{array}$ & $42.9 \%$ & $28.6 \%$ & $28.4 \%$ \\
$\begin{array}{l}\text { expensive for their means } \\
\text { Liking luxury is liking a superficial way of life }\end{array}$ & $61.8 \%$ & $22.6 \%$ & $15.6 \%$ \\
$\begin{array}{l}\text { Luxury and sustainability are contradictory } \\
\text { Luxury has no future in a world driven by sustainability }\end{array}$ & $36.6 \%$ & $27.4 \%$ & $36.1 \%$ \\
\hline
\end{tabular}

Answers are evenly distributed between respondents who are not interested in sustainability when purchasing luxury (32\%), those who are interested $(35 \%)$, and those who have no opinion (30\%). On average, results show that respondents report not to be interested in sustainability when purchasing luxury products (mean $=2.9$, std. dev. $=$ 1.26). Recall that such a question is subject to a social desirability bias: the size of the group of respondents who declare that they are indeed interested in sustainability when they buy luxury is likely to be overestimated.

Besides, $71 \%$ of respondents reported that luxury brands should be exemplary in terms of sustainability (mean $=4.0$, std. dev. $=1.02$ ) and $69 \%$ indicate that, given the price of luxury, it would be shocking to learn that these brands are not compliant 
(mean $=3.92$, std. dev. $=1.11)$. These figures clearly show that although sustainability is not (yet) part of the explicit requirements expressed by customers when buying luxury, it is already clearly part of their latent expectations. This leads to validate the hypothesis H1 stating that luxury customers are likely to ignore sustainability issues in their luxury purchases; as well as hypothesis H2 stating that luxury consumers are likely to hold high expectations regarding the sustainability orientation of luxury brands.

Regarding associations and opinions about luxury, luxury is seen as a symbol of social inequality (40\%), also as something that encourages consumers to spend beyond their means $(62 \%)$. As such, this social dimension of luxury consumption is particularly critical. $46 \%$ associate it with products of superior quality. Interestingly more than a third $(37 \%)$ of these luxury buyers associate luxury with a superficial lifestyle. The latter result confirms the data of Ipsos' world luxury tracking survey worldwide. A third of Ipsos respondents, from all countries, both mature and emerging, do declare luxury to be a superficial life style. Clearly these luxury buyers are conscious of the weakness of their behaviour. Finally, it is the main focus of this research, 34\% of the respondents believe that luxury and sustainability are contradictory $(32 \%$ believe that luxury does not belong to a world focused on sustainability), while $36 \%$ believe they are not contradictory $-30 \%$ remain undecided. In sum, luxury brands have yet to convince a majority of their own customers that their practices are consistent with the principles of sustainability. Not to talk about all the non-buyers who are generally more critical, emphasising the provocative waste and excess dimensions of luxury spending.

We then analysed in depth our hypothesised determinants of the perceived contradiction between luxury and sustainability: respondent's own luxury definition and age.

Table 4 Perceived contradiction between luxury and sustainability depending on customers' salient definition of luxury and on customers' age

\begin{tabular}{|c|c|c|c|c|}
\hline & & \multicolumn{3}{|c|}{ Perceived contradiction between sustainability and luxury } \\
\hline & & Low & High & Total \\
\hline \multicolumn{5}{|c|}{ Groups based on their first attribute defining luxury } \\
\hline \multirow[t]{2}{*}{ Price } & $\mathrm{N}$ & $34_{\mathrm{a}}$ & $80_{\mathrm{b}}$ & 114 \\
\hline & $\%$ & $29.8 \%$ & $70.2 \%$ & $100.0 \%$ \\
\hline \multirow[t]{2}{*}{ Rarity } & $\mathrm{N}$ & $49_{\mathrm{a}}$ & $106_{\mathrm{b}}$ & 155 \\
\hline & $\%$ & $31.6 \%$ & $68.4 \%$ & $100.0 \%$ \\
\hline \multirow[t]{2}{*}{ Hedonism } & $\mathrm{N}$ & $51_{\mathrm{a}}$ & $66_{\mathrm{a}}$ & 117 \\
\hline & $\%$ & $43.6 \%$ & $56.4 \%$ & $100.0 \%$ \\
\hline \multirow[t]{2}{*}{ Exclusive } & $\mathrm{N}$ & $60_{\mathrm{a}}$ & $62 \mathrm{a}$ & 122 \\
\hline & $\%$ & $49.2 \%$ & $50.8 \%$ & $100.0 \%$ \\
\hline \multirow[t]{2}{*}{ Exceptional quality } & $\mathrm{N}$ & $158_{\mathrm{a}}$ & $147_{\mathrm{b}}$ & 305 \\
\hline & $\%$ & $51.8 \%$ & $48.2 \%$ & $100.0 \%$ \\
\hline \multirow[t]{2}{*}{ Others } & $\mathrm{N}$ & $39_{a}$ & $52_{\mathrm{a}}$ & 91 \\
\hline & $\%$ & $42.9 \%$ & $57.1 \%$ & $100.0 \%$ \\
\hline \multirow[t]{2}{*}{ Total } & $\mathrm{N}$ & 391 & 513 & 904 \\
\hline & $\%$ & $43.3 \%$ & $56.7 \%$ & $100.0 \%$ \\
\hline
\end{tabular}

Note: Different letters refer to significant differences between columns (test-z $\mathrm{p}<.05$ ). 
Table 4 Perceived contradiction between luxury and sustainability depending on customers' salient definition of luxury and on customers' age (continued)

\begin{tabular}{|c|c|c|c|c|}
\hline & & \multicolumn{3}{|c|}{ Perceived contradiction between sustainability and luxury } \\
\hline & & Low & High & Total \\
\hline \multicolumn{5}{|c|}{ Groups based on age } \\
\hline \multirow[t]{2}{*}{$18-34$} & $\mathrm{~N}$ & $115_{\mathrm{a}}$ & $238_{\mathrm{b}}$ & 353 \\
\hline & $\%$ & $32.6 \%$ & $67.4 \%$ & $100.0 \%$ \\
\hline \multirow[t]{2}{*}{$35-54$} & $\mathrm{~N}$ & $158_{\mathrm{a}}$ & $187_{\mathrm{a}}$ & 345 \\
\hline & $\%$ & $45.8 \%$ & $54.2 \%$ & $100.0 \%$ \\
\hline \multirow[t]{2}{*}{$55-75$} & $\mathrm{~N}$ & $120_{\mathrm{a}}$ & $97_{\mathrm{b}}$ & 217 \\
\hline & $\%$ & $55.3 \%$ & $44.7 \%$ & $100.0 \%$ \\
\hline \multirow[t]{2}{*}{ Total } & $\mathrm{N}$ & 393 & 522 & 915 \\
\hline & $\%$ & $43.0 \%$ & $57.0 \%$ & $100.0 \%$ \\
\hline
\end{tabular}

Note: Different letters refer to significant differences between columns (test-z $\mathrm{p}<.05$ ).

Regarding the definition of luxury, the results show significant differences across groups $\left(\chi^{2}[5]=27,774, p<0.001\right)$ : the perception of the contradiction between luxury and sustainability depends on respondent's definition of luxury. Table 4 shows that customers defining luxury mainly by its price or its rarity express a strong contradiction between luxury and sustainability $(70 \%$ and $68 \%$ respectively, $\mathrm{p}<0.05)$. In contrast, customers defining luxury mainly by its exceptional quality tend to perceive a lower contradiction $(52 \%, \mathrm{p}<0.05)$. The difference is not significant for respondents whose definition of luxury is essentially based on exclusivity. This leads to validate hypotheses $\mathrm{H} 3$ (a), H3(b) and $\mathrm{H} 3(\mathrm{~d})$.

Similarly, regarding the age of respondents, the results show significant differences across cohorts: the younger the consumers, the more likely they are to perceive a contradiction between luxury and sustainability $\left(\chi^{2}[2]=30,146, p<0.001\right)$. Among younger consumers (18-34 years), a majority perceives a contradiction between luxury and sustainability. Among older consumers (55-75 years), a majority does not see any contradiction. The age group 35-54 showed no significant difference. This leads to validate the hypothesis $\mathrm{H} 4$ suggesting that the perceived contradiction between luxury and sustainability decreases with age customers. They have more experience and lived at a time where conspicuous logos did have the importance they have today. There is an issue about the new generations if luxury wants to reinforce its legitimacy for the future.

\section{Conclusions}

This study shows that although a minority of luxury customers includes sustainability in their purchase decisions, it remains that more customers have very marked expectations with respect to the sustainable orientation of luxury brands. This finding suggests that sustainability has become an element of quality expected by luxury customers. It is not surprising to find that expensive products that would not respect the environment and 
society would not only disappoint customers but even create anger. Sustainability has become an implicit need without having previously been an expressed one (Berger et al., 1993). This result clearly suggests a high risk for brands that ignore these requirements, all the more in a context where they are increasingly subject to criticism because of their visibility. For some brands, it is becoming urgent to bridge the gap between expectations and reality in order to preserve their reputation, or even to maintain their license to operate. Keeping sustainable development as a corporate prerogative is not enough anymore: this was a defensive attitude, treating the topic as a global one. Now each brand must be able to move forward and prove it is concerned: this does not mean being positioned as the most sustainable brand of the market. The demand is not here and the investments required to modify the whole supply chain would not pay back. It means demonstrating that a step by step progressive modification and control is taking place with high goals at the end. Luxury is by definition the highest quality: it has to redefine quality.

The study then focused on the perceived contradiction between luxury and sustainability. The results show that the contradiction is lower for customers who define luxury as extreme quality. It is instead much more intense for those who define luxury as expensive or rare, two factors which induce high selectivity if not discrimination of clients. As a result, if the luxury brands do not communicate directly on sustainable features of their products or services, they will have to increasingly highlight product quality, their being handmade, their rare craftsmanship rather than only rarity of supply or high price. In the last years, more and more luxury houses have intensified communication activities on the social networks around the values of luxury such as the use of extreme quality materials and talented craftsmen. This is the case of Hermès with the film 'Hands of Hermès' or of LVMH group who created the 'Special Days' to provide transparency regarding production. This must be pursued for everyone is not convinced: many clients interviewed in this study do define luxury on quality criteria $(33 \%)$, but this is still not yet the case for the majority of respondents. Another facet which must be emphasised by the luxury industry to boost its legitimacy and public support is the fact that - unlike fashion and mass-produced items -, true luxury does not delocalise its production, and aims at revitalising traditional savoir-faire and companies which without it might have disappeared. In a globalised world, luxury brands not only stand for the values of their country of origin, but should be made there (Kapferer, 2012a): this is why tourists visit their stores in Paris.

This article is focused on consumers, their expectations and unspoken dimensions that lead to a better fit between luxury and sustainability. As such, it provides a useful source of information for luxury brands. Moreover, it is a pioneering study to identify important factors affecting the perception of sustainability in the luxury sector.

A limitation of this study is the self-reported measures of the purchases. Future studies should include objective assessments (such as observations) regarding the behaviour of the subjects. Another limitation is that the study was conducted exclusively from French luxury customers. Certainly France is one of world leading luxury producing countries, and still the fifth luxury market in the world (just by-passed by China in 2013): however more than ever, luxury is global and luxury research will less and less rely on the opinion of a single nationality. These international studies which encompass both emerging and mature economies are now underway. 


\section{References}

Achabou, M.A. and Dekhili, S. (2013) 'Luxury and sustainable development: is there a match?', Journal of Business Research, Vol. 66, No. 10, pp.1896-1903.

Bain \& Co. (2014) World Luxury Market Report, May, Milano, Italy.

Bendell, J. and Kleanthous, A. (2007) Deeper Luxury Report, WWF, London.

Berger, Ch., Blauth, R., Boger, D., Bolster, Ch., Burchill, G., DuMouchel, W., Pouliot, F., Richter, R., Rubinoff, A., Shen, D., Timko, M. and Walden, D. (1993) 'Kano's methods for understanding customer-defined quality', Center for Quality Management Journal, Fall, Vol. 2, No. 4, pp.3-36.

Bhattacharya, J. and Sen, G. (2004) 'Doing better at doing good', California Management Review, Vol. 47, No. 1, pp.9-24.

Brundtland Commission (1987) Our Common Future, Brundtland Report, United Nations World Commission on Environment and Development (WCED).

Carrigan, M. and Attalla, A. (2001) 'The myth of the ethical consumer - do ethics matter in purchase behavior?', Journal of Consumer Marketing, Vol. 18, No. 7, pp.560-577.

Claudio, A. (2007) 'Waste couture', Environmental Health Perspectives, Vol. 115, No. 9, pp.449-454.

Davies, I., Lee, Z. and Ahonkhai, I. (2012) 'Do consumers care about ethical luxury?', Journal of Business Ethics, Vol. 106, No. 1, pp.37-51.

De Barnier, V., Falcy, S. and Valette-Florence, P. (2012) 'Do consumers perceive three levels of luxury? A comparison of accessible, intermediate and inaccessible luxury brands', Journal of Brand Management, Vol. 19, No. 7, pp.623-636.

Dickson, M.A. (2001) 'Utility of no sweat labels for apparel consumers: profiling label users and predicting their purchases', The Journal of Consumer Affairs, Vol. 35, No. 1, pp.96-119.

Ehrich, K. and Irwin, J.R. (2009) 'Willful ignorance in the request for product information', Journal of Marketing Research, Vol. 42, No. 3, pp.266-277.

Fombrun, C. and Shanley, M. (1990) What's in a name? Reputation building and corporate strategy', Academy of Management Journal, Vol. 33, No. 2, pp.233-258.

Gardetti, M.A. and Torres, A.L. (2014) Sustainable Luxury: Managing Social and Environmental Performance in Iconic Brands, Greenleaf Publishing, London.

Gladwin, T.N., Kennelly, J.J. and Krause, T-S. (1995) 'Shifting paradigms for sustainable development: implications for management theory and research', The Academy of Management Review, Vol. 20, No. 4, pp.874-907.

Janssen, J., Vanhamme, J., Lindgreen, A. and Lefebvre, C. (2014) 'The catch-22 of responsible luxury', The Journal of Business Ethics, Vol. 119, No. 1, pp.45-47.

Jones, T.M. (1991) 'Ethical decision making by individuals in organizations: an issue contingent model', Academy of Management Review, Vol. 16, No. 2, pp.366-395.

Kapferer, J-N. (2010) 'All that glitters is not green: the challenge of sustainable luxury', The European Business Review, November-December, pp.40-45.

Kapferer, J-N. (2012a) 'Why luxury should not delocalize: a critique of a growing tendency', The European Business Review, March-April, pp.58-62.

Kapferer, J-N. (2012b) 'Abundant rarity: key to luxury growth', Business Horizons, Vol. 55, No. 5, pp.453-462.

Kapferer, J-N. (2015) Kapferer on Luxury: How Can Luxury Brands Grow Yet Remain Rare?, Kogan Page, London.

Kapferer, J-N. and Bastien, V. (2012) The Luxury Strategy: Break the Rules of Marketing to Build Luxury Brands, Kogan Page, London.

Kapferer, J-N. and Michaut, A. (2014a) 'Is luxury compatible with sustainability: luxury consumers viewpoint', Journal of Brand Management, Vol. 21, No. 1, pp.1-22. 
Kapferer, J-N. and Michaut, A. (2014b) 'Are luxury purchasers really insensitive to sustainable development?', in Gardetti, M.A. and Torres, A.L. (Eds.): Sustainable Luxury, Chapter 7, Greenleaf Publishers, London.

Kleiber, G. (1999) La sémantique du prototype, Presses Universitaires de France, Paris.

Leary, R.B., Vann, R.J., Mittelstaedt, J.D., Murphy, P.E. and Sherry, J.F. (2014) 'Changing the market one behavior at a time', Journal of Business Research, Vol. 67, No. 9, pp.1953-1958.

Maignan, I. and Ferrell, O.C. (2001) 'Corporate citizenship as a marketing instrument- concepts, evidence and research directions', European Journal of Marketing, Vol. 35, Nos. 3/4, pp.457-484.

Mason, J. (2000) 'Conspicuous consumption and the positional economy', Managerial \& Decision Economics, Vol. 21, Nos. 3/4, pp.121-132.

McAdam, R. and Leonard, D. (2003) 'Corporate social responsibility in a total quality management context: opportunities for sustainable growth', Corporate Governance, Vol. 3, No. 4, pp.36-45.

Rapport Annuel Ethicity (2013) Les Français et la consommation responsable, Paris.

Roberts, J.A. (1995) 'Profiling levels of socially responsible consumer behavior: a cluster analytic approach and its implications for marketing', Journal of Marketing Theory and Practice, Fall, Vol. 21, pp.97-117.

Silverstein, M. and Fiske, N. (2003) 'Luxury for the masses', Harvard Business Review, Vol. 81, No. 4, pp.48-57.

Thomas, D. (2007) Deluxe: How Luxury Lost Its Luster, Penguin Books, London.

Wheeler, D., Colbert, B. and Freeman, E.R. (2003) 'Focusing on value: reconciling corporate social responsibility, sustainability and a stakeholder approach in a network world', Journal of General Management, Vol. 28, No. 3, pp.1-28. 